\title{
Earnings Predictability of Quoted Firms in Nigeria
}

\author{
Taiwo Azeez Olaniyi $P h D$ \\ Department of Accounting, University of Ilorin, Nigeria \\ E-mail: niyitaiwo03@yahoo.com \\ Segun Abogun $P h D$ \\ Department of Accounting, University of Ilorin, Nigeria \\ E-mail: segunstc@yahoo.com \\ Mudathir Olanrewaju Salam $P h D$ \\ Department of Accounting, University of Ilorin, Nigeria \\ E-mail: salamudathir@yahoo.com
}

\begin{abstract}
The inability of investors to predict future earnings of firms exposes them to further risk such that potential investors may be scared away while existing ones may be prompted to withdraw their investment. Thus, it becomes imperative to evaluate the earnings predictability of Nigerian quoted firms with a view to establish the ability or inability of earnings to predict itself. Also, the study examined the impact of volatility on earnings predictability of Nigerian quoted firms. The total number of seventy three (73) quoted Nigerian firms constitutes the population of this study and the entire 73 firms were studied. The causal relationship research design was adopted. The secondary data used were collected from the financial statements of the quoted firms for the period I996 to 2015. The system generalized method of moment (GMM) was used to estimate the dynamic panel regression models of the study. The study found that earnings of firms are predictable. The study also found that volatility has adverse effect on earnings predictability. It was therefore recommended more interest/investment in Nigerian firms since earnings information is available and is predictable while managements of firms should reduce instability in reported earnings.
\end{abstract}

Keywords: Earnings, Predictability, Volatility, Investment, Decision.

JEL Classification: M, M4.

\section{Introduction}

Risk is an important issue that investors consider in making investment decisions, especially in developing economies such as Nigeria. This is because developing economies are characterized by uncertainties and risks. Such risks may be an operating risk, information risk, political risk, technology risk, and economic risk. Earnings quality which is an element of information risk environments of developing economies refers to the adequacy, reliability, and relevance of information provided by the accounting system about the earnings of an entity. It therefore becomes difficult for investors to make investment decision due to the problem of predicting expected future cash flow arising from earnings. According to Dechow, Ge and Schrand (20I0), the quality of earnings depends on two factors: (i). operational performance of the firm, and (ii). quality of the accounting systems that measures the performance. Although there are different measures of earnings quality but the commonly used ones in the literature are value relevance, conservatism, timeliness, persistence, smoothness, accrual quality, and predictability.

The primary focus of this study is the predictability of earning as a measure of earnings quality of listed companies in Nigeria. The motivation for this study and the choice of this proxy as a measure of earnings quality came from two sources. Firstly, those who studied the time series properties of corporate earnings documented that such series follows a random walk process; that is unpredictable (Ball \&Watts, 1972; Abbrecht, Lookabill \&McKeown, 1977; Chant, I980; Afego, 2012; Ogege \& Mojekwu, 2013).

The implications of such conclusion which is a source of concern to financial analysts, investors, management, and researchers are of many folds. The first implication is that it becomes practically impossible to predict future earning by studying the histories of corporate earnings (past observations on earnings). Another implication is that investors who value firms based on the prediction of future earnings through the assessment of past performances are merely engaged in a futile exercise. Lastly, income smoothening engaged by management aimed at removing fluctuations from reported earnings which is dependent on predictability is impossible. 
It is on this basis that this study examines the predictability of earnings of the Nigerian firms. Asides the fact that the Nigerian Stock Market an emerging market, the market is highly regulated market (Nigerian Stock Exchange, 20I5; Oludoyi, 1999). Thus, the conclusion that corporate earnings are unpredictable may not be applicable to the Nigerian Market.

The second source of motivation for this study is based on one of the objectives of financial reporting which states that: the purpose of financial reporting is to provide information for existing and potential investors, lenders and other creditors for decision making (International Accounting Standard Board [IASB], 20I0). It is expected to provide information that would enable investors to assess the amount, timing, and uncertainty of expected future net cash inflows of firms. It is also expected to provide information that would enable investors to estimate the value of an entity.

The empirical evidences about these stated objectives have been inconclusive; hence the need for more evidences especially from emerging market such as Nigeria. While some studies provide evidence of good earning quality in terms of earning persistence and predictability (Folsom, Hribar, Mergenthaler, \& Peterson, 2016), others concluded that current earnings are only capable of predicting future cash flow and not future earnings (Bandyopadhyay, Chen, Huang \& Jha, 20I0). However, a number of other studies concluded that current year's cash flow other than current year's earnings predicts future earnings better (Artikis \& Papanastasopoulos, 2016). The question is: what is the predictability of earnings of the Nigerian firms?

Efforts have been made by few studies to examine the predictability of earnings of the Nigerian firms; however such studies are limited in many ways. The studies include: Ebirien and Nwanyanwu (2017); Uwuigbe, Uyoyoghene, Jafaru, Uwuigbe and Jimoh (2017). One major limitation of past studies in this area in Nigeria is that they failed to examine the impact of earnings volatility on earnings predictability which has been reported by some studies in other economies as a key determinant of predictability (Dichev \&Tang, 2009; Hamzavi \& Aflatooni, 20I I; Yosra \& Fawzi, 2015).

Another key limitation of the past studies is the weakness of the estimation techniques used. Most of these studies either used the Pooled Ordinary Least Square Method or the Ordered Probit Regression using the Maximum Likelihood Estimation technique to fit their regression models (e.g Uwuigbe, Uyoyoghene, Jafaru, Uwuigbe and Jimoh (2017). This is a major limitation of the past studies in the sense that, the use of OLS to estimate an auto-regressive model is capable of undermining the validity of findings from such studies. The model that estimates earnings predictability is an Auto-Regressive (A R (I)) model which the Ordinary Least Square and other similar estimation techniques cannot appropriately estimate. This study attempts to fill this gap in the literature. Finally, the few studies that have attempted to evaluate earnings predictability of Nigerian firm focused on the financial service sector; thereby limiting the generalization of findings from such studies.

This study attempts to address these limitations by studying all sectors except the financial service sector. Therefore, the objectives of this study are to: (I). examine the predictability of earnings of Nigerian firm; (2). examine the link between volatility of earnings and earnings predictability. As a result, the study hypothesized that: (I). earnings of Nigerian firms are not predictable; (2). earnings volatility does not affect earnings predictability.

This study covers the period from year 1996 to year 2015 for listed firms on the Nigerian Stock Exchange excluding firms in the financial sector. The choice of the start date was based on data availability. Choosing a much earlier date would reduce the number of companies included in the study as there are limited numbers of companies whose historical data is accessible. On the other hand, choosing a much later year would limit how far the study could assess the historical behavior of earnings of firms. The choice of the end date was equally based on data availability. As at the time of the study, the annual report and accounts of companies used in this study were not all available.

\section{Literature Review}

\section{Concept of Earnings Predictability and Volatility}

Earnings predictability is one of the various measures of earnings quality (Francis et al., 2004; Dechow et al., 2010). It measures the ability of earnings to predict itself; and this is possible if the firm's earnings exhibit a steady growth over the years which can also be reasonably maintained in the future periods (Fink, 2014). Lipe, (I990) defined earnings predictability as "the ability of past earnings to predict future earnings, and it is reflected in the variance of the shock in the univariate earnings process." This definition shows that earnings predictability is measured as the variance of the error term in a model where current year earnings of firm $\mathrm{J}$ is regressed on one year lag of earnings for firm J.

According to Lipe (1990), the variance of the shock in a univariate earnings model is negatively related to earnings predictability, that is, as the variance of the shock gets smaller, predictability increases. Consequently the investors' responsiveness to earnings increases. Alternatively, instead of just taking the variance of the shock as the measure of predictability, Li, Abeeysekera, and Ma (2014) used the standard deviation to measure predictability. Both variance and standard deviation measure variability or spread in a distribution; the only advantage of standard deviation over variance is that, standard deviation is in the same unit with the raw data.

It is important to note that there is difference between earnings persistence and predictability. The former measures the recurring nature of earnings. It measures the magnitude of past earnings in the current earnings. According to Dechow et al. (2010), "firms with more persistent earnings have a more sustainable earnings/cash flow stream that will make a more useful 
input into discounted cash flow based on equity valuation." On the other hand, predictability is the earnings power; meaning the ability of past earnings to predict future earnings.

Lipe (1990) differentiate the two concepts this way: "the predictability of earnings is a function of the average absolute magnitude of the annual earnings shocks, whereas the time series persistence of earnings reflects the autocorrelation in earnings." In a univariate earnings model, earnings persistence is the slope coefficient of one year lag of earnings while earnings predictability is measured as the standard deviation of the error component (annual earnings shock) in the model. Therefore, the two concepts of earnings persistence and predictability are not the same. However, the two concepts are complementary in the sense that an earnings series that exhibit persistence is most likely to be predictable.

There are determinants of earnings predictability which are also related to the determinants earnings quality in general. These determinants are classified into two: accounting related factors and economy related factors. The accounting related factors include: accrual quality, earnings smoothness, earnings management, measurement error, accounting conservatism (Ewert \& Wagenhofer, 2010). The economic related factors are the core operating performance of firms and earnings volatility.

Earnings volatility is the variability in earnings which is capable of reducing the ability of past earnings to predict future earnings (Dichev \& Tang, 2009; Luttman \& Silhan, 2017). According to Fink (20I4), volatility is the instability and inconsistency of pattern exhibited by the earning stream of a company. When the value of earnings is rising and falling in an indiscernible manner, such earnings distribution is said to be volatile.

The volatility of earnings may be attributed to the volatility of the economy within which a firm operates. In an emerging market such as Nigeria where government economic policies change frequently in an inconsistent manner, firms are adversely affected (Espinosa, 2016; Roggi, Giannozzi \& Baglioni, 2016). For instance, the persistent fluctuation in the foreign exchange of Nigerian local currency against the US dollar and Pounds has negative effect on the operational performance of some firms. This fluctuation in the FOREX can introduce volatility into fundamental performance of firms. Therefore, the policy and operating environment within which a firm operate influences the volatility introduced into earnings. More so, the Nigerian economy has witnessed recession in the recent time. The effect of such economic shock can equally affect the economic performance of firm.

Furthermore, apart from the economic volatility, accounting principles and practices are equally capable of introducing volatility into earnings (Fink, 20I4). In situations where revenue is poorly matched with expenses, volatility is introduced into earnings (Dichev \& Tang, 2008). Also, the accuracy of accounting estimates, depreciation of asset method used, and stock valuation methods can determine the level of volatility exhibited by earnings. In addition, the accounting practice of timely recognition of losses than gains, transaction based accounting are capable of making earnings to be volatile

The implications of earnings volatility are numerous: It reduces earnings persistence and predictability (Dichev \&Tang, 2009); it reduces the information content of earnings (Collin \&Kothari, I989; Lipe, I990). It also signals uncertainty to the market and as a result, the market revises downward its expectations about the future prospects of the firm. Consequently, the stock price is adversely affected (Luttman \& Silhan, 20II). The cost of capital is high due to the uncertainty of expected future net cash inflow into the entity. The effect of that is that cost of external finance will be relatively high when compared with internal sources (Ewert \& Wagenhofer, 2010; Bruner, Conroy, Estrada, Kritzman, \& Li, 2010; Doneva \& Strom, 2013). Volatility also creates incentives for management to smoothen and manage earnings for personal gains (Hamzavi \& Aflatooni, 201 I).

\section{Theoretical Explanation \\ Valuation Theory}

According to Feltham and Ohlson (I995); Dumontier and Raffournier (2002); Nilsson (2003), valuation theory posits that the value of a firm is the present value of the expected future dividend. Furthermore, by imposing the clean surplus relation assumption, the value of a firm is measured as the sum of the book value of equity and present value of future expected abnormal earnings; where abnormal earning is the difference between current earnings and a capital charge. The capital charge is measured as book value of equity at the beginning multiplied by discount rate. The clean surplus relation assumption stipulates that change in the book value of equity is equal to current earnings minus dividend. Ohlson (1995) made another assumption by imposing an auto-regressive behavior on abnormal earnings. This last assumption introduces the persistence parameter and consequently earning predictability into valuation model.

Therefore, from equity valuation perspective, predictability is a key determinant of how well earnings information can be used to value firms (Ohlson, 1995; Dechow et al., 2010; Luttman \& Silhan, 20II). Share price reacts to earnings information, precisely the earnings power (Graham \& Dodd, 2009). Lipe (1990) demonstrated that the earnings response coefficient (ERC) has positive link with earnings persistence and predictability. It means that revision of expectation by the market in response to earnings information is an increasing function of earnings persistence and predictability. The earnings response coefficient (ERC) measures the responsiveness of investors to earnings information (Dechow et al., 2010; Collins \& 
Kothari, 1989). This is because investors are mostly concerned with the current position of an organization and equally the future prospects of the organization.

However, in a situation where future earnings are uncertain, it becomes difficult to value the security of a firm. If earnings are not predictable, it becomes difficult for investors to determine the earnings power of the security; hence, investors cannot know whether to buy, sell, or hold the security of the firm. Consequently, the market tends to revise downward its expectation about the future expected net cash inflow of such firms. This has many implications for the firm. Firstly, the cost of capital which is the expected return on investments by provider of capital to the firm would be high. This high cost of capital is to cater for the risk of investing in a stock whose future net cash inflow is uncertain (unpredictable). Secondly, when the market writes downward its expectation about the future prospect of a firm, the share price of such firm is priced low by the market. If such situation is not addressed, after some time it may lead to a take-over bid by a healthier company.

Another consequence of earnings unpredictability is that such firm may find it difficult to source for external finance (Hasan, Park \& Wu, 2012). This is because lenders would find it difficult to predict the ability of such firm to redeem loans or any other facility; and a result they would be unwilling to give out facility to the firm.

\section{Random Walk Theory}

In other to specify the empirical model of this study, the random walk theory is applied. The theory stipulates that the successive price changes in security prices is not dependent; making it difficult to predict future price of security. Those who attempt to predict future price of security using past observations believe that history has a way of repeating itself. It is believed that if an intelligent person understands the pattern of past behavior of security prices, and volume of trading, he could possibly predict tomorrow's price of security. Those who hold this view are usually referred to as technical analysts. In contrast, the advocates of random walk theory state that successive changes in security prices are without pattern; hence, it is impracticable to predict security prices (Arewa \& Nwakanma, 20I4).

The empirical model of a random walk theory according to Dupernex (2007) can be stated as:

$\mathrm{X}_{\mathrm{t}}=\lambda_{0}+\mathrm{X}_{\mathrm{t}-\mathrm{I}}+\gamma_{\mathrm{t}}$ where $\mathrm{X}_{\mathrm{t}}$ represents current year security price, $\mathrm{X}_{\mathrm{it}-\mathrm{I}}$ is the previous value of security, $\lambda_{0}$, is a drift component and $\gamma_{\mathrm{t}}$ is the stochastic error term which is identically independently distributed. Therefore, for the purpose of empirical analysis relevant for this work, an auto-regressive of order one is specified in section three of this study.

\section{Empirical Review}

Many research efforts have been made towards understanding and describing the time series properties of corporate earnings for decision making, depending on the decision objective. This has been approached in the literature from two different points of view. The advocates of the first approach believe that the behavior of corporate earnings can be understood by modeling the time series behavior of past earnings. The objective of the approach is to extrapolate/forecast future earnings by developing univariate earnings model using past earnings. The technique commonly used by the proponents of this approach is the autoregressive method, ranging from auto-regressive model of order one AR (I), auto-regressive moving average (ARMA), to the auto-regressive integrated moving average (ARIMA). They found that the behavior of corporate earnings is similar to the random walk process (Ball \& Watts 1972; Watts and Leftwich, 1977; Albrecht, lookabill \&Meckeown 1977). The primary implication of these findings is that corporate earnings are not predictable using past earning.

This approach to earnings predictability has been criticized for its many limitations. Chant (I980) claimed that forecasting of earnings using its past values alone is not the best approach to understand the predictability of earnings. It was said that future earnings cannot be predicted in isolation from other economic variables or information. Chant (I980) designed an alternative measure of earnings predictability which posits that earnings information is a subset of the generality of public information. More so, it is believed that earnings are economic variables that easily interact with other economic variables. As a result, econometric model was used instead of a univariate earnings model. In this case, a dependent variable versus independents variables in a regression model was used. This econometric regression model allows for the inclusion of past values of earnings and other independent variables. This enables the past values of earnings to relate with other information sets to jointly predict future earnings. This approach is consistent with the work of Lipe (1990); Das, Levine, \& Sivaramakrishnan (I998), Luttman and Silhan (20II); Hamzavi and Aflatooni (20II); Dichev and Tang (2009); Yosra and Fawzi (20I5); Fama and French (2000); Ewert and Wagenhofer (2010).

Findings from these studies are diverse; however, evidence of earnings predictability is common in most of the studies. Some of the explanatory variables examined in conjunction with past values of earnings are: smoothness, volatility, accrual quality, firm characteristics, conservatism, and profitability. Studies have revealed that volatility is inversely related to earnings predictability (Allayannis, Rountree, \& Weston, 2005; Dichev \& Tang, 2009; Yosra \& Fawzi, 20I5). The result of Hamzavi and Aflatooni (201I) showed that earning smoothing is positively related to predictability. This latter finding should be interpreted with caution in the sense that earnings smoothing engaged by management using discretionary accrual is not desirable. The work of Uwuigbe et al. (2017) shows that current earnings' ability to predict future earnings decreased after the 
adoption of International Financial Reporting Standard. Similarly, the work of Ebirien \& Nwanyanwu (2017) reveals that there is no evidence of significant difference between banks and insurance firms in the ability of earnings to predict future earnings. For the purpose of this study, the two approaches to earnings predictability were adopted. The first model in section three of this study is a univariate earnings model. The second model is not a univariate model but included volatility as another independent variable; hence it is consistent with the alternative approach.

\section{Methodology \\ Model Specification}

The purpose of this study is to measure the predictability of earnings of Nigerian listed firms; and as a result, the autoreg ressive model of order one (I) is specified. Consistent with the specifications in the work of Das et al. (1998); Francis et al. (2004); Richardson, Sloan, Soliman \& Tuna (2005); Dechow et al. (2010); Boubakri (2012); Park and Shin (2015); Artikis and Papanastasopuolos (2016), the model is specified as:

Earningsit $=\eta_{\mathrm{o}}+\eta_{\mathrm{I}}$ Earningsit-I $+\delta_{\mathrm{i}}+\pi_{\mathrm{it}}$

Where Earningsit is the current earnings for the various firms for the period covered, $\eta_{\mathrm{o}}$ is the intercept of the model, that is, the constant term, $\eta_{\mathrm{I}}$ is the persistence parameter, Earningsit-I is the immediate past value of current earnings, $\delta_{i}$ is the time-invariant individual firm characteristics, and $\pi_{\text {it }}$ is the stochastic error term.

The above specification of autoregressive model is considered suitable for this study since the objective is to determine the ability of past earnings to predict future earnings. The word autoregressive in this case means the inclusion of lagged dependent variable as an independent variable in the model. If the lagged dependent variable is solely the independent variable, then the model is a univariate model.

In addition to the univariate model in equation ( $\mathrm{I}$ ), equation (2) below measures the impact of volatility on earnings predictability. As a result, volatility is interacted with earnings as the second explanatory variable in the autoregressive model apart from the lagged dependent variable. Therefore, following the works of Dichev and Tang (2009); Hamzavi and Aflatooni (201 I); Yosra and Fawzi (2015) the model is specified as:

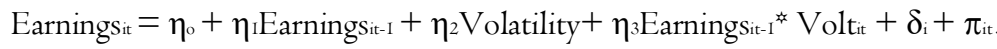

In order to measure predictability from equation (I), the standard deviation of the stochastic error term is used. The slope coefficient of the lagged dependent variable in equations I\&2 is not interpreted the usual way of interpreting the slope coefficient of the classical linear regression model. In this case, the autoregressive coefficient is used to measure the persistent level of earnings. The closer it is to I, the more persistent the earnings, but the closer it is to zero, the less persistent, and the more transitory the earnings.

There is a positive link between earnings persistence and earnings predictability. Persistence of earnings drives the predictability of earnings such that high level of persistence would result to increased ability of earnings to predict itself. According to Dichev and Tang (2009), "the strength of the direct relation between earnings volatility and earnings predictability is determined by earnings persistence, where higher persistence signifies more predictable earnings".

However, for the purpose of measuring predictability, it is the standard deviation of the error term that is used. The smaller the standard deviation of the error term, the higher the predictability of earnings and vise-versa. This interpretation is consistent with Francis et al. (2004); Dichev and Tang (2009); Li et al. (20I4). On the other hand, if the objective of the research design is to measure the predictability of earnings relative to volatility, then the $\mathrm{R}^{2}$ from the regression models in equations I and equation 2 are used to measure predictability of earnings (Dichev \&Tang, 2009; Petrovic, Manson, \& Coakley, 2009; Ewert \& Wagenhhofer, 2010; Hamzavi \& Aflatooni, 20II; Yosra \& Fawzi, 20I5). If the $\mathrm{R}^{2}$ is high then the predictability of earnings is high; otherwise the predictability of earnings is low. According to Dichev and Tang (2009), the value of $R^{2}$ if predictability is relative to volatility is calculated as the squared of persistence coefficient (in this case $\eta_{I}$ in equations $I \& 2)$.

The volatility of earnings is measured as the coefficient of variation of the entire historical earnings for each firm over the period covered. This measurement is in line with the study of Das et al., (1998). The coefficient of variation is calculated as (standard deviation/mean) $)^{*}$ IOO (Black, 2010).

\section{Estimation Techniques}

Equations (I) \& (2) are dynamic panel regression models. Therefore, for the purpose of estimation, Arellano and Bond (I99I) stated that attention should be paid to certain economic problems that may come up. Firstly, the inclusion of the lagged 
dependent variable as explanatory variable introduces autocorrelation. Secondly, the lagged dependent variable is correlated with the individual characteristic. However, if the model is transformed by taking its first difference, then the effect of the individual characteristic disappears. Nevertheless, the lagged dependent variable is still correlated with the lagged error term. Thirdly, it is possible that some of the explanatory variables are endogenous; in that case, the explanatory variables would correlate with the error. Fourthly, the panel data set is such that the time period (time dimension) is less than the cross-sectional units (unit dimension). The implication of these economic problems is that the Pooled Ordinary Least Square Estimator, Fixed Effect Panel Estimator, and the Random Effect Panel Estimator are biased and inconsistent. Therefore, in order to overcome these problems, the Blundell and Bond (I998) System Generalized Method of Moment (GMM) estimator is used.

\section{Research Design}

In this study, the ability of past earnings to predict future earnings is examined. Following the past studies in this field of research, current year earnings were regressed on its lagged value and the variance of the error was obtained. Consequently, the standard deviation of the error (square root of the error variance) measures the predictability of earnings. As a result of the procedure followed in measuring predictability of earnings in this study the causal relationship research design was used.

\section{Population, Sample and Data}

The population of this study consists of all the companies listed on the Stock Exchange not later than year I996. The year I996 was chosen due to the nature of this study which requires historical data. This population does not include companies in the financial sector on the basis that the sector is highly regulated such that its inclusion may constitute a serious heterogeneity problem in the study. In total, seventy three (73) companies constitute the population of this study; and the entire seventy three (73) companies were examined to enhance the generalization of the findings. Hence, the study is a census study since no sample was selected.

For the purpose of this study, secondary data were used and were obtained from the financial statements of the companies studied. The data obtained was the earnings information for all the firms studied. Earnings are measured as the profit on ordinary activities after tax.

\section{Analysis and Results}

Table Imodel I presents the estimation result of the system dynamic panel for modelI. The result shows that the lagged dependent variable (Earningsit-I) which is the autoregressive component of the model has a coefficient of 0.7238752 and it is significant at $\mathrm{I} \%$ levels $(\mathrm{p}<0.0 \mathrm{I})$. The $\mathrm{R}^{2}$ for the model is obtained by taking the square of the autoregressive coefficient as 0.52 . The model was properly fitted as shown by the significance $(\mathrm{p}<0.0 \mathrm{I})$ of the Wald Statistics. Also, table I.2 shows that the absolute value of the standard deviation of the error term for model I is I37I8I8. Furthermore, the coefficient of correlation between earnings and the lagged value of earnings is 0.8754 as contained in table I.3. The implication of this result is that half of the total variation in earnings is explained by its own history, therefore it can be deduced that there is evidence of earnings predictability.

\section{Table I Model I: System Gmm Panel Regression Results}

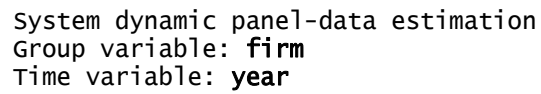

\begin{tabular}{|c|c|c|c|c|c|c|}
\hline earnings & coef. & $\begin{array}{l}\text { WC-Robust } \\
\text { Std. Err. }\end{array}$ & z & $P>|z|$ & [95\% Conf. & Interval] \\
\hline $\begin{array}{r}\text { earnings } \\
\text { L1. } \\
\text { _cons }\end{array}$ & $\begin{array}{r}.7238752 \\
391880.4\end{array}$ & $\begin{array}{r}.0003463 \\
4730.169\end{array}$ & $\begin{array}{r}2090.42 \\
82.85\end{array}$ & $\begin{array}{l}0.000 \\
0.000\end{array}$ & $\begin{array}{r}.7231965 \\
382609.4\end{array}$ & $\begin{array}{r}.7245539 \\
401151.3\end{array}$ \\
\hline
\end{tabular}

Instruments for differenced equation GMM-type: L(2/.).earnings

Instruments for level equation GMM-type: LD.earnings Standard: _cons

Source: Authors' Computation, (2019)

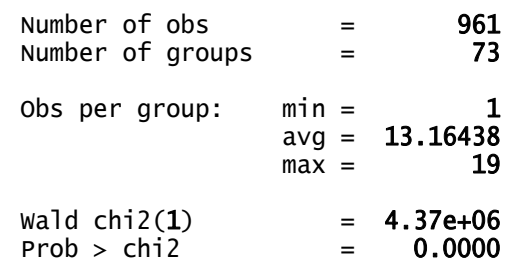


Table I.2 - Standard Deviation of Residual

\begin{tabular}{r|r} 
stats & resid \\
\hline mean & 127.9957 \\
variance & $1.88 \mathrm{e}+12$ \\
sd & 1371818 \\
$\max$ & $1.37 \mathrm{e}+07$ \\
$\mathrm{CV}$ & 10717.69 \\
$\min$ & -8165224 \\
\hline
\end{tabular}

Table I.3- CORRELATION MATRIX

\begin{tabular}{r|lll} 
& \multicolumn{3}{|c}{ earnings earngs $\sim$ volati y } \\
\hline earnings & 1.0000 & & \\
earngsLag & 0.8754 & 1.0000 & \\
volatility & 0.0765 & 0.0777 & 1.0000
\end{tabular}

Source: Authors' Computation, (2019)

However, the result equally implies that almost half of the total variation in earnings is explained by other factors other than the history of itself. It can be said therefore that evidence of earnings predictability is just moderate and not so high. This result is consistent with the work of Holt (2013) who found evidence of earnings predictability. On the other hand, the result is different from the results reported by Ebirien and Nwanyanwu (2017); Uwuigbe et al. (2017) who found no evidence of earnings predictability. The inconsistency in findings especially in Nigeria may be attributed to the fact that the works of Ebirien and Nwanyanwu (2017); Uwuigbe et al. (2017) were focus on the financial service sector while this study focus on other sectors other than the financial sector.

Furthermore, in order to examine the effect of earnings volatility on earnings predictability, model 2 was estimated and the results are contained in table 2 , model 2 . This table shows that the autoregressive coefficient is 0.775673 and it is significant at $\mathrm{I} \%$ significance level $(\mathrm{p}<0.0 \mathrm{I})$. The table also reveals that the coefficient of the interaction between the lagged dependent variable and volatility is -0.0766498 and it is significant at $\mathrm{I} \%$ significance level $(\mathrm{p}<0.0 \mathrm{I})$. Adjusting for the effect of volatility, the autoregressive coefficient is added to the interaction coefficient as $0.775673+(-0.0766498)$ which is equal to 0.6990232 . This figure is used to obtain the value of $\mathrm{R}^{2}$ for model 2 as $(0.6990232)^{2}$ which is equal to 0.49 . Furthermore, table 2.I reveals that the standard deviation of the error term for model 2 is I706428. It shows that the autoregressive coefficient dropped after adjusting for the effect of volatility. Also, the value of $\mathrm{R}^{2}$ dropped after adjusting for volatility.

\section{Table 2 Model 2}

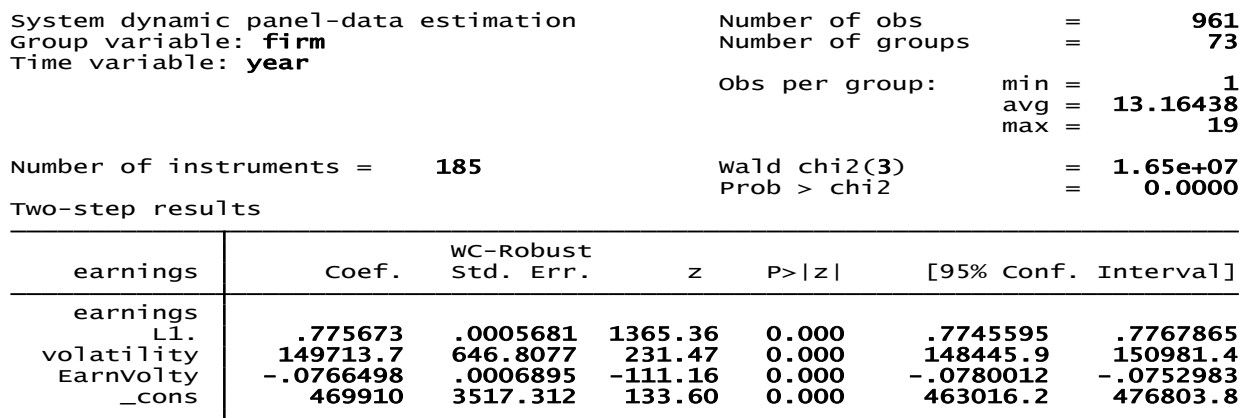

Instruments for differenced equation

GMM-type: L(2/) ) earnings

Standard: D.Earnvolty

Instruments for 1 evel equation

GMM-type: LD.earnings

Source: Authors' Computation, (2019) 
Table 2.I Standard Deviation of Residual

\begin{tabular}{r|r} 
stats & residv t \\
\hline mean & 53.79413 \\
$\min$ & -7871149 \\
$\max$ & $1.36 \mathrm{e}+07$ \\
$\mathrm{cV}$ & 31721.45 \\
$\mathrm{sd}$ & 1706428 \\
\hline
\end{tabular}

Source: Authors' Computation, (2019)

Similarly, the standard deviation of the error term increased from I37I8I8 in model I to I706428 in model 2. The implication of this result is that since the autoregressive coefficient reduced after adjusting for the effect of volatility and the standard deviation of the error term increased, volatility has negative effect on predictability of earnings. This result is consistent with the findings of Hamzavi \& Aflatooni (20II) who found that smoothness of earnings has positive association with earnings predictability. This result is also consistent with the works of Dichev and Tang (2009); Flink (2014); Yosra and Fawzi (2015) who found that volatility has inverse relationship with earnings predictability. The table 3 shows the distributions of earnings, interaction variable, lagged value of earnings and earnings volatility. The model is well fitted because the Wald statistics is significant at $\mathrm{I} \%$, that is $\mathrm{p}<0.0 \mathrm{I}$. The total number of instruments used was $\mathrm{I} 85$ and they were valid instruments. The validity of the instruments was established based on the result of the Sargan test contained in table 4 . The null hypothesis could not be rejected at any of the significance levels; meaning that the instruments used were valid.

Table 3 Descriptive Statistics

\begin{tabular}{r|rrrrr} 
Variable & obs & Mean & \multicolumn{1}{l}{ Std. Dev. } & Min & Max \\
\hline Earnvolty & 1046 & 902224.6 & 2583053 & $-2.82 e+07$ & $2.81 e+07$ \\
earnings & 1071 & 1029076 & 2480202 & -2752268 & $1.89 \mathrm{e}+07$ \\
earnLag & 1046 & 972330.5 & 2319159 & -2752268 & $1.79 \mathrm{e}+07$ \\
volatility & 1201 & -.523869 & 7.199037 & -44.8958 & 17.78263
\end{tabular}

Source: Authors' Computation, (2019)

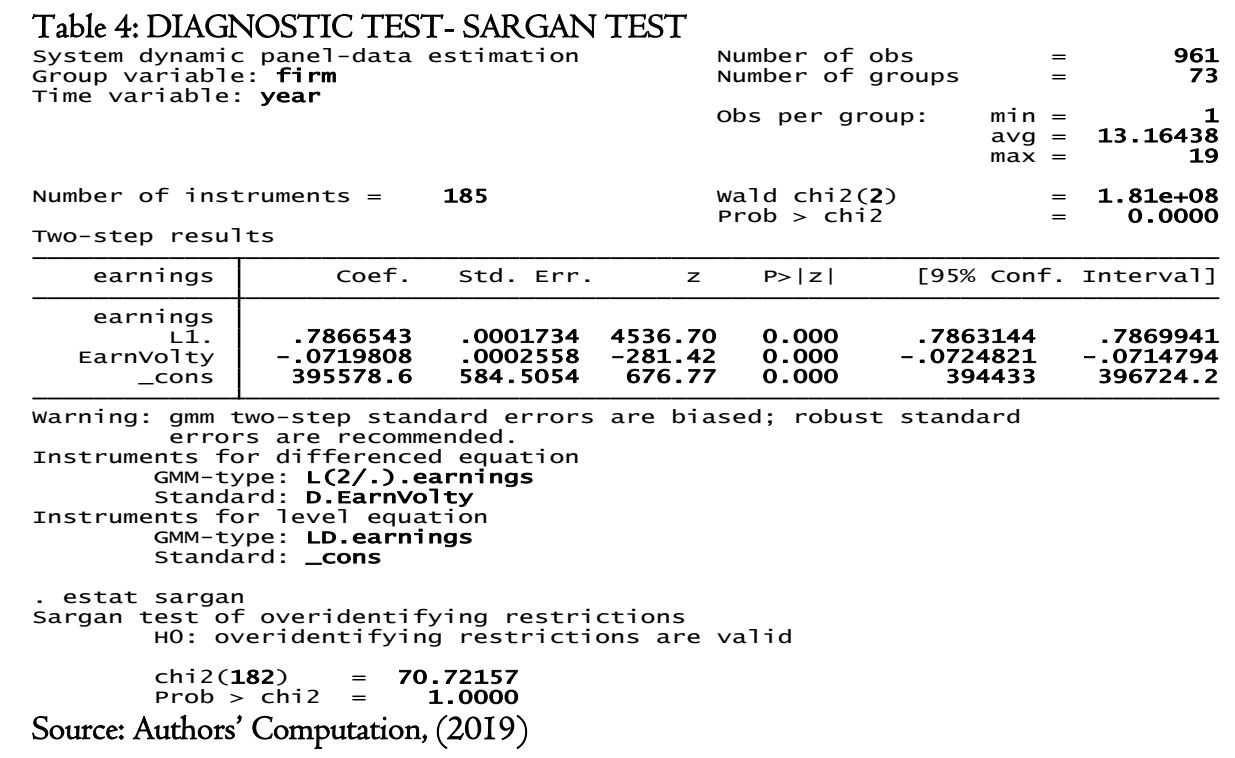




\section{Summary, Conclusion and Recommendations}

This study evaluated the predictabiliy of earnings of Nigerian firms and it found that the ability of earnings to predict its elf is evident. More so, the study evaluates the impact of earnings volatility on earnings predictability. The study found that volatiliy has adverse effect on earnings predictability.

The study therefore concludes that earnings of Nigerian firms have ability to predict themselves which by implication means that investors can moderately determine the amount, timing and uncertainty of future cashflow on their investments. However, volatility of earnings has negative effect on the ability of earnings of Nigerian quoted firms to predict itself.

It was therefore recommended that both foreign and local investors should invest their wealth in Nigerian firms since the risk of future earnings can be moderately determined from past values of earnings. Secondly, since volatility adversely affects earnings predictability management of firms should ensure smoothness of earnings. However, the practice of smoothening earnings using private information to get personal gains is not encouraged because it is capable of misleading investors and other users of earnings information.

\section{References}

Afego, P. (2012). Weak form efficiency of the Nigerian Stock Market: An empirical analysis (1984-2009). International Journal of Economics and Financial Issues, 2(3), 340-347.

Albrecht, W. S., Lookabill, L. L., \& McKeown, J. C. (1977). The time series properties of annual earnings. Journal of Accounting Research, I5(2), 226-244.

Allayannis, G., Rountree, B. \&Weston, J. P. (2005). Earnings volatility, cash flow volatility and firm value. Retrieved $6^{\text {th }}$ July, 2017 from https://faculty.fuqua.duke.edu/seminarscalendar/Rountree.doc

Arellano, M. \& Bond, S. (I99I). Some tests of specification for panel data: Monte Carlo evidence and an application to employment equations. Review of Economic Studies, 58, 277-297.

Arewa, A. \& Nwakanma, P. C. (2014). Re-validating weak-form hypothesis Nigerian capital market: A comparative test analysis. International Business Research, 7(4), 73-83

Artikis, P. G., \& Papanastasopoulos, G. A. (2016). Implications of the cash component of earnings for earnings persistence and stock returns. The British Accounting Review, 48(2), II7-I33.

Ball, R. \& Watts, R. (1972). Some time series properties of accounting income. The Journal of Finance, 27, 663-68I.

Bandyopadhyay, S. P., Chen, C., Huang, A. G., \& Jha, R. (2010). Accounting Conservatism and the Temporal Trends in Current Earnings' Ability to Predict Future Cash Flows versus Future Earnings: Evidence on the Trade-off between Relevance and Reliability. Contemporary Accounting Research, 27(2), 4I3-460.

Black, K. (2010). Business statistics: For contemporary decision making ( $6^{\text {th }} \mathrm{ed}$.), Hoboken: John Wiley \&Sons

Boubakri, F. (2012). The relationship between accruals anomaly in the Canadian context. International Journal of economics and Finance, 4(6), 5I-62.

Bruner, R. F., Conroy, R.M., Estrada, J., Kritzman, M., \& Li, W. (2010). Introduction to 'valuation in emerging market'. Emerging Market Review, 3(310-324)

Chant, P. D. (I980). On the predictability of corporate earnings per share behavior. Journal of Finance, 35(I), I3-2 I.

Collins, D.W. \& Kothari, S.P. (I989). An analysis of inter-temporal and cross-sectional determinants of earnings response coefficients. Journal of Accounting and Economics, II(I43-I8I).

Das, S., Levine, C. B., \& Sivaramakrishnan, K. (1998). Earnings predictability and bias in analysts' earnings forecasts. The Accounting Review, 73(2), 277-294.

Dechow, P., Ge, W., Schrand, C. (2010). Understanding earnings quality: A review of the proxies, their determinants and their consequences. Journal of Accounting and Economics, 50, 344-40I.

Dichev, I. D., \& Tang, V. W. (2008). Matching and the changing properties of accounting earnings over the last 40 years. The Accounting Review, 83(6), I425-I460.

Dichev, I. D., \& Tang, V. W. (2009). Earnings volatility and earnings predictability. Journal of Accounting and Economics, 47(I/2), I60-I8I.

Doneva, V. \& Strom, J. (2013). Credit rating and investment decision in emerging market. Unpublished Master Dissertation, School of Economics and Management, Lund University

Dumontier, P., \& Raffournier, B. (2002). Accounting and capital markets: A survey of the European evidence. European Accounting Review, II(I), II9-I5I.

Dupernex, S. (2007). Why might share prices follow a random walk? Student Economic Review, 21, I67-I79.

Ebirien, G. I. \& Nwanyanwu, L. (2017). Earnings quality of firms in the Nigerian financial services sector. European Journal of Accounting, Auditing and Finance Research, 5(4), 54-64.

Espinosa, P. (2016). On value in the emerging markets. SEAFARER Capital Partners, LLC, SEA00047I

Ewert, R., Wagenhofer, A. (2010). Earnings quality metrics and what they measure. 
Fama, E. F. \& French, K. R. (2000). Forecasting profitability and earnings. Journal of Business, 73(2), I6I-I75.

Feltham, G. \& Ohlson, J. A. (I995). Valuation and clean surplus accounting for operating and financial activities. Contemporary Accounting Research, II(2), 689-73I.

Folsom, D., Hribar, P., Mergenthaler, R. D., \& Peterson, K. (2016). Principles-based standards and earnings attributes. Management Science, 63(8) http://pubsonline.informs.org/doi/abs/I0.1287/mnsc.2016.2465

Francis, J., Lafond, R., Olsson, P., \& Schipper, K. (2004). Costs of equity and earnings attributes. The Accounting Review,79(4), 967-I0I0.

Fink, J. (2014). Valuing stocks using a snapshot multiple requires earnings predictability. Retrieved on $6^{\text {th }}$ June, 2017 from https://www.investingdaily.com/20643/valuing-stockusing-a-snapshot-multiple-requires-earnings-predictability-2

Graham, B., \& Dodd, D. L. (2009). Security analysis: Principles and techniques (6 ${ }^{\text {th }} \mathrm{ed}$.), New York: McGrawHill.

Hamzavi, M. A. \& Aflatooni, A. (201 I). Earnings smoothing and earnings predictability. Business Intelligence Journal, 4(I), I87-20I.

Hasan, I, Park, J. C., \& Wu, Q. (20I2). The impact of earnings predictability on bank loan contracting. Journal of Business Finance and Accounting, 39(7-8), 1068-I I0I.

Holt, P. (2013). Earnings quality as measured by predictability of reported earnings. Advances in Business Research, 4(I), 4953.

International Accounting Standard Board (IASB, 2010). Conceptual framework for financial reporting. Retrieved from http://www.ifrs.org/News/Press-Releases/Documents/ConceptualFW20IOvb.pdf.

Li, F., Abeysekera, I., \& Ma, S. (20I4). The effect of financial status on earnings quality of Chinese-listed firms. Journal of Asia-Pacific Business, I5(I), 4-26.

Lipe, R. (1990). The relation between stock return and accounting earnings given alternative information. Accounting Review, 65(I), 49-7I.

Luttman, S. M. \& Silhan, P. A. (20II). An empirical analysis of the value line earnings predictability index. Journal of Applied Business Research, 9(4), I04-109.

Luttman, S. M. \& Silhan, P. A. (20I7). Determinants of earnings variability. Journal of Applied Business Research, I I(I), I I7I24.

Nigerian Stock Exchange Rule Book (2015)

Nilsson, H. (2003). Essays on the value relevance of financial statement information. Retrieved from http://www.divaportal.org/smash/get/diva2:I4254I/FULLTEXTOI.pdf

Ogege, S., \& Mojekwu, J. N. (2013). Econometric investigation of the random walk hypothesis in the Nigerian stock market. Journal of emerging issues in economics, I(5), 38I-400.

Ohlson, J. (1995). Earnings, book values, and dividends in equity valuation. Contemporary Accounting Research, I I(2), 66I687.

Oludoyi, S. B. (1999). Understanding risk in a regulated market: evidence from the Nigerian stock markets. African Journal of Economic Policy, 6(2), 59-76.

Park, S. \& Shin, H.(2015). Earnings persistence over the macroeconomic cycle: Evidence from Korea. The Journal of Applied Business Research, 3I(6), 2I47-2I66.

Petrovic, N., Manson, S., \& Coakley, J. (2009). Does volatility improve UK earnings forecasts? Journal of Business Finance and Accounting, 36(9-I0), II48-II79.

Richardson, S. A., Sloan, R. G., Soliman, M. T., \& Tuna, I. (2005). Accrual reliability, earnings persistence and stock prices. Journal of Accounting and Economics, 39, 437-485.

Roggi, O., Giannozzi, A., \& Baglioni, T. (2016). Firm valuation in emerging markets and the exposure to country risk. Global Journal of Management and Business Risk, I6(I), I-20.

Uwuigbe, U. Uyoyoghene, A. L., Jafaru, J., Uwuigbe, O.R. \& Jimoh, R. (20I7). IFRS adoption and earnings predictability: Evidence from listed banks in Nigeria. Bank and Bank Systems, I2(I), I66-I74.

Watts, R. L. \& Leftwich, R. W. (1977). The time series of annual accounting earnings. Journal of Accounting Research, I5(2), 253-27I.

Yosra, B. M. \& Fawzi, J. (20I5). Earnings volatility and earnings predictability. Journal of Business Studies Quarterly, 6(3), 37 53.

Copyrights

Copyright for this article is retained by the author(s), with first publication rights granted to the journal. This is an open-access article distributed under the terms and conditions of the Creative Commons Attribution license (http://creativecommons.org/licenses/by/4.0/). 